\title{
Analisis Paparan Pornografi dan Dampaknya Terhadap Pembelajaran Matematika SMP
}

\author{
Ezra Silalahi ${ }^{1}$, Islamiani Safitri ${ }^{2}$ \\ ${ }^{1,2}$ Program Studi Pendidikan Matematika, Fakultas Keguruan dan Ilmu Pendidikan, Universitas Labuhanbatu, \\ J1. Sisingamangaraja No 126 A KM 3.5, Rantauprapat, Indonesia \\ esrasilalahi2606@gmail.com
}

\begin{abstract}
Pornography is a problem that is still a frightening thing in the community, especially if children who are exposed are school age children. Therefore, to reduce these problems, a preliminary study on the analysis of exposure to pornography in adolescence is necessary. This study aims to see the exposure to pornography in mathematics learning at SMP Negeri 1 Na IX $-X$ in class IX-3. In this study using a qualitative method with a case study approach. The subjects in this study were students of class IX-3 SMP Negeri $1 \mathrm{Na}$ IX-X. The instrument in this research is using interviews, observation documentation and questionnaires. The research time was carried out in a period of 3 months. The results of this study indicate that there are $8.5 \%$ of students exposed to pornography in class IX-3. The conclusion is that students should avoid things that are pornographic, because pornography has a very negative impact on sexual behavior, such as having an impact on development and ways of thinking. Students are required to spend their time for positive activities such as participating in religious and extracurricular activities at school. Students are expected to understand again the development of adolescents about how to master social implementation skills according to gender, so that students do not violate rules in social relations with the opposite sex.
\end{abstract}

Keywords: Exposure to pornography, Mathematics learning

\begin{abstract}
Abstrak
Pornografi merupakan salah satu masalah yang sampai saat ini masih menjadi hal yang menakutkan di kalangan masyarakat, terutama jika yang terpapar adalah anak di usia sekolah. Oleh karena itu, untuk mengurangi permasalahan tersebut perlu dilakukan studi pendahuluan tentang analisis paparan pornografi di usia remaja. Penelitian ini bertujuan untuk melihat paparan pornografi pada pembelajaran matematika di SMP Negeri $1 \mathrm{Na}$ IX -X yang ada di kelas IX-3. Pada penelitian ini menggunakan metode kualitatif dengan pendekatan studi kasus. Subjek dalam penelitian ini yaitu siswa kelas IX-3 SMP Negeri 1 Na IX-X. Instrumen dalam penelitian ini yaitu menggunakan wawancara, observasi dokumentasi dan angket. Waktu penelitian dilakukan dalam jangka waktu selama 3 bulan. Hasil dari penelitian ini menunjukan bahwa terdapat 8,5\% siswa yang terpapar pornografi pada kelas IX-3. Kesimpulan yang di dapatkan bahwa siswa siswa harus menghindari hal yang bersifat pornografi, karena pornografi sangat berdampak negatif pada prilaku seksual, seperti berdampak pada perkembangan dan cara berfikirnya. Siswa diwajibkan untuk melungakna waktunya untuk kegiatan yang positif seperti mengikuti kegiatan keagamaan dan ekstrakulikuler yang ada disekolah. Siswa diharapkan untuk memahami lagi perkembangan remaja tentang bagaimana cara menguasai kemampuan pelaksanaan sosial sesuai dengan jenis kelamin, agar siswa tidak melanggar peraturan dalam hubungan sosial pada lawan jenisnya.
\end{abstract}

Kata kunci: Paparan pornografi Pembelajaran Matematika

Copyright (c) 2019 Ezra Silalahi, Islamiani Safitri

$\triangle$ Corresponding author: Ezra Silalahi

Email Address: islamiani.safitri @gmail.com (Jl. Sisingamangaraja No 126 A KM 3.5, Rantauprapat, Indonesia)

Received 02 Desember 2020, Accepted 12 Maret 2021, Published 12 Maret 2021

\section{PENDAHULUAN}

Pornografi merupakan salah satu isu yang diperbincangkan oleh masyarakat, sejak adanya Undang-undang tentang, anti pornografi dan pornoaksi pada tahun 2006, dimana undang-undang anti pornografi telah mendefenisikan bahwa pornografi sebagai gambar, sketsa, ilustrasi, foto, tulisan, 
suara, gambar bergerak, animasi, atau percakapan dan lainnya melalui berbagai bentuk media komunikasi (Utomo, 2018). Meluasnya pornografi selalu berhubungan dengan internet sebagai sarana penyebarannya. Dampak dari pornografi yaitu siswa lebih sering menonton dan membaca pornografi kemudian siswa lebih cenderung meniru dan melakukan seksual seingga lebih tidak fokus pada sekolah.(Mendrofa, Tinggi, \& Kesehatan, 2019)

Pada Pembelajaran matematika di sekolah diharapkan mampu mewujudkan tujuan pembelajaran matematika yang dirumuskan oleh Pada Tahun ajaran 2013 pemerintah mulai menerapkan kurikulum baru yaitu kurikulum 2013. Berdasarkan Permendikbud Nomor 70 Tahun 2013 kurikulum 2013 bertujuan untuk mempersiapkan manusia Indonesia agar memiliki kemampuan hidup sebagai pribadi dan warga negara yang beriman, produktif, kreatif, inovatif, dan afektif serta mampu berkontribusi pada kehidupan bermasyarakat, berbangsa, bernegara, dan peradaban dunia. Kurikulum 2013 yang diberlakukan secara bertahap pada pendidikan nasional saat ini menekankan pentingnya keseimbangan kompetensi sikap, pengetahuan, dan keterampilan.(Kuncara, Sujadi, \& Riyadi, 2016)

Menurut WHO, remaja adalah penduduk dalam rentang usia 10-19 tahun, menurut Peraturan Menteri Kesehatan RI Nomor 25 tahaun 2014, remaja adalah penduduk dalam rentang usia 10-18 tahun dan menurut Badan Kependudukan dan Keluarga Berencana (BKKBN) rentang usia remaja adalah 10-24 tahun dan belum menikah. Masa remaja adalah masa peralihan atau masa transisi dari anak menuju masa dewasa. Pada masa ini begitu pesat mengalami pertumbuhan dan perkembangan baik itu fisik maupun mental (Haidar \& Apsari, 2020).

Salah satu perubahan yang terjadi pada masa remaja adalah adanya perubahan yang berkaitan dan berhubungan dengan perkembangan psikososial, perubahan pada hubungan dengan orang tua, pembentukan orientasi masa depan, munculnya perilaku-perilaku negatif atau kenakalan remaja seperti merokok, narkoba, penyalahgunaan pemakaian internet dan media komunikasi, akses pornografi, dan penyalahan seksualitas.(Utomo, 2018)

Kemajuan teknologi dewasa ini memudahkan para siswa untuk memperoleh informasi dari media massa teknologi pada saat ini. Informasi seperti ini cenderung menjerumuskan remaja/siswa pada permasalahan seksual dan tingkah laku seksual yang tidak bertanggung jawab. Hal ini bisa menyebabkan pemahaman yang keliru tentang pendidikan seks, sehingga siswa bisa terjebak dari dalam perilaku seksual yang menyimpang pesat pada saat ini. Karena banyaknya remaja di Indonesia yang sudah kecanduan dalam kemajuan teknologi dewasa dimana para siswa sudah terjebak pada konten porno atau konten ponografi yang sering dibuka atau ditonton oleh para remaja saat ini.

Kondisi ini membuat para remaja ingin mencari tau informasi dari berbagai situs atau sumber dengan lebih mudah untuk mengakses berbagai hal yang mereka inginkan, seperti yang kita ketahui bahwa perkembangan teknologi zaman sekarang sangat cepat dibuktikan dengan adanya internet, youtube, google dan media lainnya (Haidar \& Apsari, 2020). Dari perkembangan teknologi ini dapat menimbulkan dampak negatif yang dapat mmpengaruhi para remaja saat ini, diantaranya yaitu 
penyalahgunaan internet untuk mengakses situs-situs pornografi. Untuk mengetahui lebih lanjut apakah ada paparan pornografi pada pembelajaran matematika di SMP Negeri 1 Na IX-X, maka diperlukan analisis mendalam tentang paparan pornografi dan dampaknya terhadap pembelajaran matematika. Dalam hal ini, peneliti menggunakan metode studi kasus untuk melihat paparan pornografi pada sebuah subjek penelitian yaitu siswa SMP Negeri Na IX-X dengan wawancara, observasi, dokumentasi, dan angket sebagai instrument dan teknik pengumpulan datanya. Adapun tujuan dari penelitian ini yaitu mendeskripsikan paparan pornografi yang ada di SMP Negeri 1 Na IX - X dan dampak paparan pornografi terhadap siswa SMP Negeri 1 Na IX - X sebagai referensi bagi peneliti selanjutnya jika ingin melakukan penelitian dengan topik yang sama.

\section{METODE}

Metode penelitian adalah suatu sistem dan metode yang ketat untuk mengatur pengetahuan tentang fenomena yang ada di sekolah. Suatu metode penelitian merupakan suatu rangkaian kegiatan yang sistematis dan terkontrol secara empirik terhadap sifat-sifat dan hubungan-hubungan antara berbagai variabel yang terdapat dalam fenomena yang diteliti (Thalha Alhamid, 2019). Penelitian ini adalah penelitian kualitatif yang menggunakan metode Studi Kasus. Dimana metode studi kasus dalam penelitian ini dilakukan untuk mencari tau kasus pornografi di SMP Negeri $1 \mathrm{Na}$ IX - X, pada kelas IX-3 yang berjumlah 34 siswa

Subjek penelitian adalah orang, tempat, atau benda yang diamati dalam rangka pembuatan sebagai sasaran yang ingin diteliti. Subjek dalam penelitian adalah siswa kelas dan wali kelas IX-3, serta kepala sekolah SMP Negeri $1 \mathrm{Na}$ IX - X. Penelitian ini memiliki dua jenis sumber data yaitu data primer dan sekunder. Data primer adalah data yang berasal dari sumber asli yang ditujukan pada siswa kelas IX-3 yang berjumlah 35 siswa di SMP Negeri 1 Na IX - X. Data sekunder ialah data yang telah tersedia dalam berbagai bentuk umum berupa bukti, catatan atau laporan yang diambil dari kepala sekolah dan wali kelas itu sendiri, karena wali kelas lebih dekat pada anak didiknya dan lebih mengenal karekter siswa tersebut, sedangkan kepala sekolah lebih tau latar belakang dari siswa yang ada dikelas IX di SMP Negeri $1 \mathrm{Na}$ IX - X.

Dalam penelitian kualitatif yang menjadi instrument atau alat penelitian adalah peneliti itu sendiri atau Human Research (Sugiyono,2013), peneliti berfungsi menetapkan fokus penelitian, memilih informan sebagai sumber data melakukan pengumpulan data, analisis data dan membuat kesimpulan. Teknik pengumpulan yang digunakan dalam penelitian ini adalah observasi, wawancara, dokumentasi dan angket. Observasi yang digunakan pada penelitian ini adalah observasi tidak berstruktur yang dilakukan tanpa menggunakan guide observasi, dimana peneliti mampu mengamati suatu objek untuk melihat dampak paparan pornografi yang terjadi pada siswa yang ada di SMP Negeri $1 \mathrm{Na}$ IX - X melihat aktivitas siswa dikelas, melihat interaksi teman dan melihat binteraksi siswa dengan guru. Wawancara yang digunakan yaitu wawancara tak berstruktur yaitu peneliti bebas menentukan fokus masalah wawancara yang akan diberikan pada guru matematika ataupun wali kelas 
dari IX-3 untuk melihat berapa banyak siswa yang membuka situs-situs pornografi dan mengetahui seberapa besar kepedulian guru terhadap siswa dalam permasalahaan situs pornografi. Pada guru pendidikan matematika yang masuk pada kelas IX-3 merupakan guru yang telah mengajar sekitar 34 tahun dan sudah berusia 57 tahun sedangkan wali kelas yang mengatur kondisi yang ada dikelas tersebut merupakan guru sudah mengajar sekitar 8 tahun dan sudah berusia 47 tahun. Dokumentasi untuk memproleh data atau informasi dari siswa yang terkena paparan pornografi yang ada di sekolah. Angket merupakan teknik pengumpulan data yang dilakukan dengan cara memberi pertanyaan kepada responden (siswa) untuk dijawab, untuk mengetahui berapa banyak siswa yang ada di kelas IX terkena paparan situs pornografi.

Teknik analisis data yang digunakan ialah Model Miles dan Huberman, analisis data dilakukan pada saat pengumpulan data berlangsung, dan setelah selesai pengumpulan data dalam priode tertentu. Miles and Huberman (1984), mengemukakan bahwa aktivitas dalam analisis data kualitatif dilakukan secara terus menerus sampai tuntas, sehingga datanya sudah jenuh. Aktivitas dalam analisisn data, yaitu data reduction, data display, dan conclusion drawing/verification (prof.Dr.Sugiono, 2013).

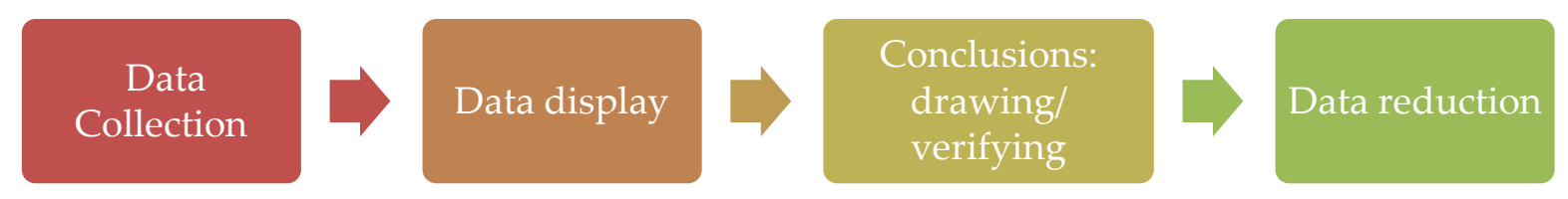

Gambar 1. Model Teknik pengumpulan data dan analisis data secara Interaktif

Data Reduction adalah data yang diproleh dari lapangan jumlahnya cukup banyak, untuk itu perlu dicatat secara teliti dan rinci. Mereduksi data berarti merangkum, memilih hal-hal yang penting, dicari tema dan polanya. Dengan demikian data yang yang telah direduksi akan memberikan gambaran yang lebih jelas, dan mempermudah peneliti melakukan pengumpulan data selanjutnya. Data Display adalah menyajikan data. Dalam pen elitian kualitatif, penyajian data bisa dilakukan dalam bentuk uraian singkat, bagan, hubungan, antar kategori, flowchart dan lainnya. Dengan menyajikan data, maka akan memudahkan untuk memahami apa yang terjadi, merencanakan kerja selanjutnya berdasarkan apa yang telah dipahami. Conclusion Drawing adalah penarikan kesimpulan dan verifikasi. Kesimpulan dalam penelitian kualitatif adalah merupakan temuan baru yang sebelumnya pernah ada. Temuan dapat berupa deskripsi atau gambaran suatu objek yang sebelumnya masih gelap sehingga telah diteliti menjadi jelas, dapat berupa hubungan kausal atau interaktif, hipotesis (Sugiono, 2013). 
Keabsahan data merupakan konsep penting yang diperbaharui dari konsep kesahihan (validitas) dan keandalan (reabilitas) menurut versi 'positivisme' dan disesuaikan dengan tuntunan pengetahuan, kriteria dan paradigmanya sendiri (Moleong,2013). Pada awalnya keabsahan data harus dilihat dari segi kriteria yang digunakan oleh non-kualitatif yang menggunakan 'validitas internal', 'validitas eksternal' dan'reliabilitas'. Pada penelitian ini keabsahan yang digunakan ialah Triangulasi dimana triangulasi adalah teknik pemeriksaan keabsahan data yang memanfaatkan sesuatu yang lain dari luar data itu untuk keprluan pengecekan atau sebagai pembanding terhadap suatu data. Menurut Moleong (2001) penelitian yang menggunakan teknik trigulasi dalam pemeriksan melalui sumbernya artinya membenadingkan atau mengecek ulang derajat kepercayaan suatu informasi yang diproleh melalui waktu dan alat yang berbeda. Triagulasi dilakukan melalui wawancara, observasi tidak langsung yang dilakukan dalam bentuk pengamatan dari beberapa kejadian, pada teknik ini untuk melengkapi dalam memproleh data primer dan data sekunder, observasi dan interview untuk menjaring data primer yang berkaitan data penelitian, sementara studi dokumentasi digunakan untuk menjaring data sekunder yang dapat diangkat dari berbagai dokumentasi yang berhubungan dengan data penelitia(Sugiono, 2013).

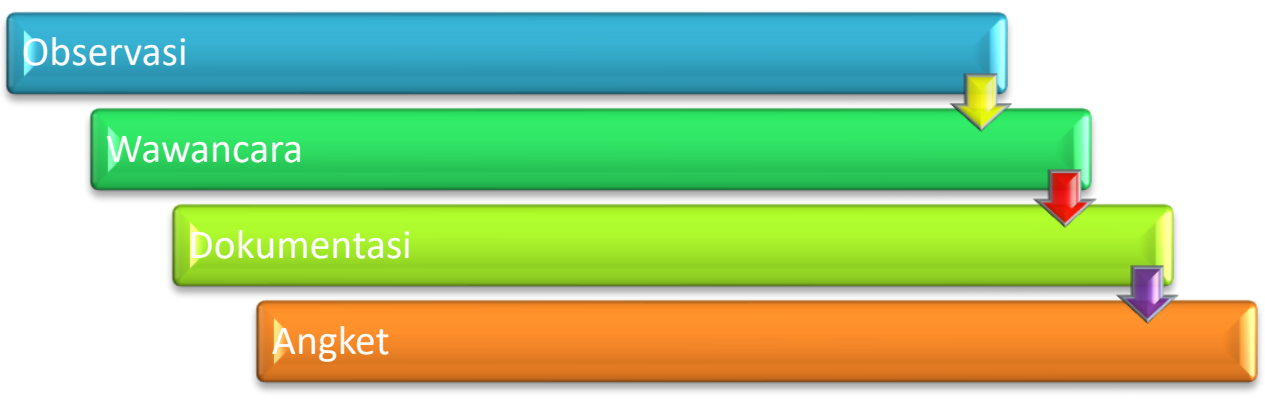

Gambar 2. Trigulasi dengan empat teknik pengumpulan data.

\section{HASIL DAN DISKUSI}

Dari hasil data trigulasi diatas bahwa dokumentasi yang didapatkan dari data atau informasi dari siswa yang terkena paparan pornografi dan kurangnya minat belajar pada pembelajaran matematika yang ada di sekolah.

Tabel 1. Hasil dokumentasi pembelajaran matematika kelas IX-3

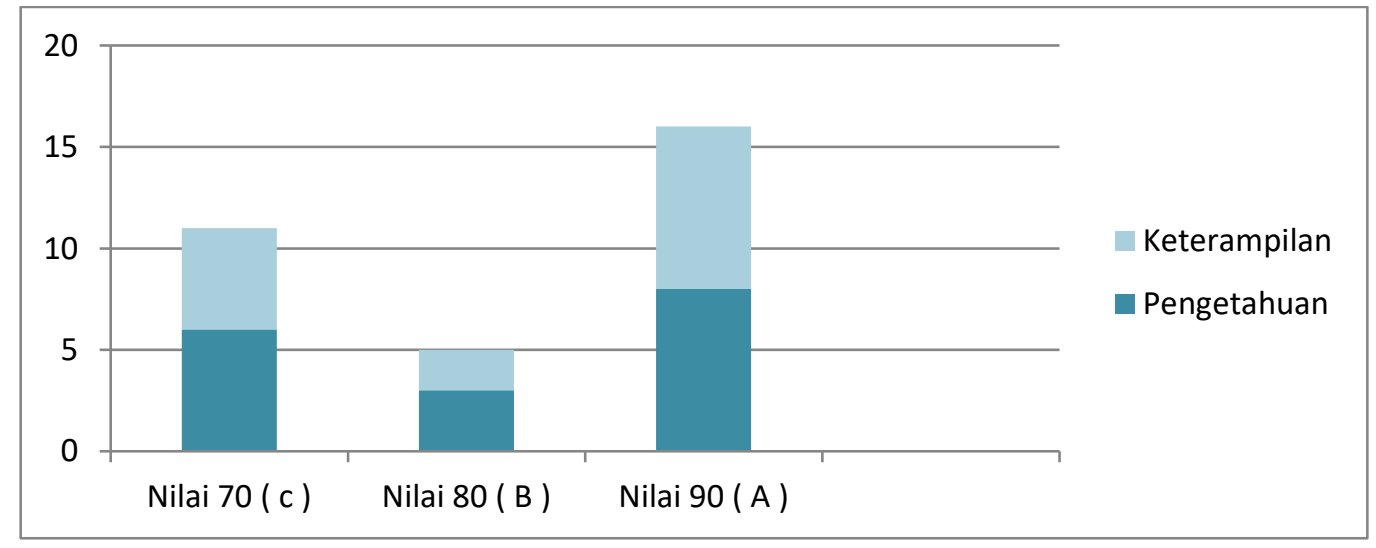


Berdasarkan hasil angket yang didapatkan untuk pengumpulan data yang dilakukan dengan cara memberi pertanyaan kepada responden (siswa) untuk dijawab, untuk mengetahui berapa banyak siswa yang ada di kelas IX terkena paparan situs pornografi.

Tabel 2. Distribusi Total Rerata Skor Hasil Kuesioner Masing-Masing Aspek (\%)

\begin{tabular}{|c|l|c|c|c|c|}
\hline No & \multicolumn{1}{|c|}{ Kategori } & Tinggi & Sedang & Rendah & $\begin{array}{l}\text { Sangat } \\
\text { Rendah }\end{array}$ \\
\hline 1 & Berpacaran & $20,5 \%$ & $0 \%$ & $0 \%$ & $0 \%$ \\
\hline 2 & Membuka Video Porno & $0 \%$ & $0 \%$ & $0 \%$ & $0,82 \%$ \\
\hline 3 & Keingintahuan & $0 \%$ & $11,7 \%$ & $0 \%$ & $0 \%$ \\
\hline 4 & Sangat Sedang & $0 \%$ & $0 \%$ & $0 \%$ & $0 \%$ \\
\hline
\end{tabular}

Hasil penelitian menunjukan bahwa terdapat adanya paparan pornografi pada siswa kelas IX3. Penjelasan lebih lanjut tentang paparan pornografi akan dibahas lebih lanjut pada sub judul di bawah ini.

\section{Analisis Paparan Pornografi}

Terjadi nya siswa yang terpapar oleh pornografi karena kenakalan remaja, kenakalan remaja meliputi semua prilaku yang menyimpang dari norma-norma argama dan yang lainnya yang dilakukan pada remaja saat ini. Prilaku kenakalan remaja merugikan dirinya sendiri dan orang-orang yang ada disekitarnya (Utomo, 2018). Didalam di dunia online memiliki konsep resiko online pada kalangan remaja dan pendidikan, Stakrud dan Livingstone mendefinisikan risiko online (online risks) sebagai satu set pengalaman heterogen yang sengaja maupun tidak sengaja yang dapat membahayakan pengguna internet; meliputi terpapar pornografi, menyakiti diri, kekerasan, rasisme atau konten kebencian, kontak dengan pelaku paedofil atau pelecehan, cyberbullying, "happy slapping" atau pelanggaran privasi (Luthfia, 2018).

Dari hasil wawancara yang dilakukan kepada wali kelas IX-3 dan guru matematika menyatakan bahwa diantara 34 siswa kelas IX-3 SMP negeri 1 Na IX-X ada yang terkena paparan pornografi. Namun, hasil wawancara peneliti dengan wali kelas mengatakan bahwa tidak ada siswa yang terpapar pornografi di kelas IX-3 Na IX-X. Berbeda dengan pernyataan guru matematika yang mengatakan bahwa di kelas tersebut pasti ada siswa yang terpapar pornografi, mengingat bebasnya akses internet dengan situs-situs yang tidak terkontrol saat ini.

Dari hasil angket menunjukan bahwa ada 8,5\% siswa yang terpapar pornografi. Maka terdapat perbedaan antara wali kelas dengan guru matematika dan hasil angket yang sudah ditliti, dimana wali kelas dengan guru matematika tidak ada pendekatan kepada siswa dan tidak menganal karakter dari masing-masing siswa nya tersebut yang mengakibatkan wali kelas tidak tau bahwa terdapat siswa dari dikelas IX-3 yang terpapar pornografi. 


\section{Dampak paparan pornografi}

Menurut Elida Prayitno (2006: 49) perubahan yang terjadi pada awal masa remaja meliputi perubahan sistem pencernaan, perubahan sistem syaraf, perubahan sistem pernafasan, dan perubahan organ seks. (Hariyani, Mudjiran, \& Syukur, 2012).

\section{Dampak Pornografi Pada Terhadap Siswa}

Intensitas membaca dan menonton pornograf pendapat Sarlito W Sarwono (2008: 165) menyatakan bahwa anak yang beranjak remaja cenderung melakukan aktifitas-aktifitas seksual yang prasenggama seperti melihat buku atau film cabul, berciuman, berpacaran dan sebagainya. Dari survei yang dilakukan oleh peneliti melalui wawancara, angket dan observasi menunjukan bahwa paparan pornografi yang ditujukan pada siswa yang ada di SMP negeri $1 \mathrm{Na}$ IX - X dikelas XI-3, kurang menggikuti pembelajan dan kurangnya minat belajar siswa dimana dari 34 siswa ada 19 siswa yang mendapatkan nilai rata-rata 75 pada pembelajaran matematika. Siswa dikelas IX-3 tidak ada minat untuk membuka dan membaca buku, adapun munculnya tingkat kejahatan pada dirinya sendiri yang mengakibatkan pelecehan seksual, pembunuhan dan pemerkosaan, sebab jika siswa tersebut dinasehati atau diteringati siswa bukan semakin diam melainkan semakin emosi dan tidak terima untuk dinasehati.

\section{Dampak Pornografi Pada Pembelajaran Matematika}

Para remaja yang masih sekolah di tingkat SMP (Sekolah Menengah Pertama) merupakan kelompok yang rentan terhadap pemaparan pornografi. Media yang mengandung substansi seksual semakin banyaktersebar di lingkungan kita dalam satu dekade terakhir. Sebagai remaja para siswa SMP sedang sangat ingintahu tentang masalah seksual tetapi sulit mengkomunikasikannya pada orangtua atau guru. Kedua kondisi tersebut memungkinkan pornografi menjadi epidemic (wabah) yang sulit dihindari dalam kehidupan para siswa SMP Negeri 1 Na IX-X. Yang mengakibatkan siswa SMP kurang nya dalam pembelajaran matematika, dikarenakan adanya media yang mengandung substansi seksual yang membuat siswa terfokus pada situs tersebut, dan membuat nilai pembelajaran matematika menjadi buruk dan kurang.

\section{Faktor-Faktor Paparan Pornografi}

Faktor-faktor paparan pornografi yang sering terjadi diakibatkan dikarenakan ada beberapa faktor yaitu:

\section{Kurangnya Perhatian Orang Tua Kepada Anaknya}

Orang tua adalah salah satu contoh tokoh pada anak-anaknya pada kehidupan sehari-hari tetapi didalam soal keagamaan hal itu seakan-akan terabaikan, sehingga mudah untuk menerima hal buruk tidak terkcuali video porno(Radjagukguk \& Yayu Sriwartini, 2020).

\section{Pengaruh Lingkungan}

Lingkungan hidup juga sangat berpengaruh pada kehidupan diri kita sendiri apalagi pada siswa SMP yang masih rentang pada media saat ini, bukan hanya pengaruh lingkungan pengaruh pacar juga bisa membuat siswa terkena situs pornografi. 


\section{Pengaruh Media Massa}

Peranan adanya media massa yang bisa membuat mereka menjadi tidak fokus kepada pemebelajaran yang ada disekolah. Dikarenakan remaja saat ini mudah terpengaruh dan ingin mencari identitas mereka sehingga mereka mudah untuk meniru atau mencontoh apa yang dia lihat pada film, gambar atau berita yang bersifat kekerasan dan sebagainya dari media massa.

\section{Perkembangan Teknologi Modern}

Dengan adanya perkembangan teknologi modern saat ini sangat mudah untuk mengakses internet sangat cepat dan online, dengan memudahkan remaja untuk mendapatkan hiburan atau video sekdual yang tidak sesuai dengan mereka melalui media internet. Didalam di dunia online memiliki konsep resiko online pada kalangan remaja dan pendidikan, Stakrud dan Livingstone (2009) mendefinisikan risiko online (online risks) sebagai satu set pengalaman heterogen yang sengaja maupun tidak sengaja yang dapat membahayakan pengguna internet; meliputi terpapar pornografi, menyakiti diri, kekerasan, rasisme atau konten kebencian, kontak dengan pelaku paedofil atau pelecehan, cyberbullying, "happy slapping” atau pelanggaran privasi (Luthfia, 2018).

Kelompok Teman Sebaya

Kelompok teman sebanyak dapat mempengaruhi pertimmbangan dan keputusan seseorang remaja tentang prilakunya (Beyth-Marom, et al., 1993; Conger, 1991; Deaux, et al1993; Papalia \& Olds, 2001). Kelompok teman sebaya merukan salah satu sumber referensi bagi kalangan remaja dalam hal persepsi dan sikap yang berkaitan dengan gaya hidup (Novita, Psikologi, Psikologi, \& Are, 2018).

Faktor lain yang mempengaruhi perilaku kenakalan pada remaja adalah konsep diri yang merupakan pandangan atau keyakinan diri terhadap keseluruhan diri, baik yang menyangkut kelebihan maupun kekurangan diri, sehingga mempunyai pengaruh yang besar terhadap keseluruhan perilaku yang ditampilkan (Kota et al., 2020).

\section{Kiat-Kiat Untuk Mengatasi Masalah Paparan Pornografi}

Adapun kiat-kiat untuk mengatasi masalah paparan pornografi ialah harus bekerjasama dengan beberapa pihak seperti guru dan orangtua, merubah dirinya sendiri dengan cara melakukan aktifitas yang positif dan ekstrakulikuler yang ada disekolah sehingga siswa yang ada dikelas IX-3 terhindar dari situs pornografi. Dalam hal ini peran orang tua yang sangat perlu untuk mengatasi permasalahan paparan pornografi dengan cara : 1.Mendampingi anak ketika mengakses internet, 2.Memberikan pemahaman anak tentang internet sehat dan aman, 3.Mengenali teman dan lingkungan s ekitarnya, 4.memberikan perhatian, kasih sayang dan penghargaan kepada anak.(Anak \& Bahaya, n.d.)

Dari hasil wawancara peneliti dengan salah wali kelas di kelas IX-3 mengatakan bahwa tidak ada salah satu siswa di kelas IX-3 yang terkena oleh paparan pornografi, dimana dengan beberapa pertanyaan yaitu:

Pertanyaan: Jika ada murid bapak yang terkena paparan pornografi apa tindakan yang bapak lakukan kepada anak tersebut? 
Jawaban:Yang saya lakukan, jika ada siswa yang terkena paparan pornografi yaitu menasehati siswa yang terkena dan terpapar oleh pornografi, kemudian wali kelas juga memberikan sangsi terhadap siswa tersebut, agar jika siswa tersebut tidak mengulangi tindakan yang sama, dan memberikan surat panggilan kepada orang tua siswa.

Pertanyaan:Bagaimana cara bapak jika ada siswa bapak yang terkena paparan pornografi?

Jawaban: Wali kelas IX-3 mengatakan cara saya mengatasi jika ada anak saya yang terkena paparan pornografi dengan cara memberikan arahan supaya anak tersebut tidak lagi untuk melihat situs-situs seperti itu. Beda dengan guru matematika yang mengatakan bahwa cara mengatasinya harus bekerjasama dengan beberapa pihak, dan harus berubah dirinya sendiri. Selanjutnya orang tua wajib memantau anak nya dirumah supaya anaknya tersebut tidak mengurung dan berdiam diri dan sering berkomunikasi.

Pertanyaan:Jika dilibatkan dengan pembelajaran, apakah anak tersebut mampu menerima dan menangkap pembelajaran?

Jawaban:Menurut saja jika anak tersebut terkena oleh paparan pornografi, dia tidak lagi mampu menerima dan menangkap pembelajaran yang diberikan oleh guru nya. Dimana anak tersebut masih tersempang di dalam memori anak tersebut dan selalu terbayang dalam pikirannya.

Pertanyaan:Apa yang bapak lihat jika ada siswa bapak yang terlibat pada situs pornografi?

Jawaban:Yang saya lihat jika jika siswa tersebut sudah terkena paparan pornografi siswa terse but leih cenderung diam dan lebih sering untuk menyendiri.

Bagaimana interaksi siswa terhadap guru, dan terhadap temannya sendiri?

Untuk saat ini interaksi siswa ke guru cukup sangat baik, belum ada perkataan kotor yangdiucapka oleh siswa terhadap gurunya sendiri. Tetapi interaksi antara sesama teman mungkin ada satu atau dua kata yang dikeluarkan ucapan kotor kepada temannya, dikarenakan mereka sering melihat dan mendengar perkataan yang tidak baik lewat media sosial atau pengaruh teman.

Berdasarkan data yang dilihat bahwa paparan pornografi yang ada di SMP Negeri $1 \mathrm{Na}$ IX $\mathrm{X}$ yaitu berpacaran, membuka video porno, perasaan keingintahuan, ketertarikan. Paparan pornografi dikumpulkan melalui kuesioner. Perolehan skor paparan pornografi di SMP Negeri 1 Na IX-X melalui kuesioner yang dikategorikan menjadi 4 yaitu tinggi, sedang, sangat rendah dan rendah. Paparan pornografi pada kelas IX -3 adalah 20,5\% siswa yang sudah berpacaran dengan kuesioner tinggi, siswa yang membuka video porno hanya $8,82 \%$ siswa dengan kuesioner sangat rendah, aspek perasaan keingintahuan memperoleh $11,7 \%$ siswa yang sedang, sedangkan ketertarikan tidak ada siswa yang melakukannya. Berdasarkan dari data yang didapatkan pada siswa kelas IX-3 yang terpapar pada pornografi memilki metode pengurangan tindak pemikiran pornografi dengan cara 
memberikan bimbingan konseling untuk mengatasi kesulitan belajar siswa dan membentuk kepribadian yang menentukan siswa menjadi manusia yang taat kepada aturan yang ada(Azkiyah, 2017).

\section{KESIMPULAN}

Berdesarkan rangkaian proses penelitian, pembahasan dan pendalaman teori yang dilakukan, maka dapat disimpulkan bahwa kecanduan pornografi sangat beresiko besar yang akan mengakibatkan siswa tidak terfokus pada pendidikan dan bisa menghancurkan masa depan mereka. Sasaran utama yang akan diserang yaitu kemampuan kognitif yang kemudian akan mempengaruhi proses berpikit (thinking), mengingat (memori) rekaman yang disimpan diotak. Dampak paparan pornografi siswa dikategorikan angat tinggi, dimana upaya guru dan orang tua mampu membimbing dalam mengatasi dampak pornografi yang ada pada dunia media.

Sesuai hasil yang ditemukan diatas, siswa harus menghindari hal yang bersifat pornografi, karena pornografi sangat berdampak negatif pada prilaku seksual, seperti berdampak pada perkembangan dan cara berfikirnya. Siswa diwajibkan untuk melungakna waktunya untuk kegiatan yang positif seperti mengikuti kegiatan keagamaan dan ekstrakulikuler yang ada disekolah. Siswa diharapkan untuk memahami lagi perkembangan remaja tentang bagaimana cara menguasai kemampuan pelaksanaan sosial sesuai dengan jenis kelamin, agar siswa tidak melanggar peraturan dalam hubungan sosial pada lawan jenisnya.

Untuk mengatasi agar siswa tidak terkenadampak paparan pornografi, guru diarapkan untuk membimbing dan mengupayakan pencegahan dampak pornografi terhadap siswa denga layanan memeberikan informasi kepada siswa dengan menggunakan gambar-gambar tentang bahayanya pornografi, agar siswa tidak terjebak dan mengikuti hal-hal yang bersifat pornografi.

\section{UCAPAN TERIMA KASIH}

Dalam hal ini, peneliti banyak mendapatkan bantuan dari berbagai pihak, kerena itu pada kesempatan kaliini peneliti mengucaokan banyak terima kasih kepada Ibu islamiani Safitri, S.Pd., M. PFis selaku dosen pembimbing yang telah membimbing peneliti dalam menyusun artikel ini. Kepala ibu Juliana Marpaung, S.Pd., MM selaku kepala sekolah SMP Negeri 1 Na IX-X yang telah bersedia menerima peneliti dalam melakukan penelitian selama bulan januari 2021. Bapak Said Harahap S. Pd selaku wali kelas IX-3 dan bapak Jono Pemly Purba S. Pd selaku guru matematika yang telah membantu peneliti dalam menyelesaikan artikel ini. Terima kasih kepada kedua orang tua penulis yang sangat luar biasa dan keluarga yang telah mendukung peneliti dalam menyelesaikan artikel ini.

Sahabat setia penulis dan rekan seangkatan 2017 dan satu bimbingan artikel serta pihak yang membantu dalam menyusun artikl ini. Semoga Tuhan Yang Maha Esa memberikan balasan pahala atas segala amal yang diberikan, dan semoga artikel ini berguna bagi semua pihak yang membaca. 


\section{REFERENSI}

Azkiyah, L. (2017). Bibliokonseling Virtual: Metode Pengurangan Tindak Pikiran Pornografi Pada Siswa Smpn 1 Karangploso. CENDEKIA: Journal of Education and Teaching, 11(2), 183. https://doi.org/10.30957/cendekia.v11i2.316

Haidar, G., \& Apsari, N. C. (2020). Pornografi Pada Kalangan Remaja. Prosiding Penelitian Dan Pengabdian Kepada Masyarakat, 7(1), 136. https://doi.org/10.24198/jppm.v7i1.27452

Hariyani, M., Mudjiran, M., \& Syukur, Y. (2012). Dampak Pornografi Terhadap Perilaku Siswa dan Upaya Guru Pembimbing untuk Mengatasinya. Konselor, 1(2), 1-8. https://doi.org/10.24036/0201212696-0-00

Kota, D. I., Studi, B., Bogor, X. K., Gayatri, S., Shaluhiyah, Z., \& Indraswari, R. (2020). Faktor Â€““ Faktor Yang Berhubungan Dengan Frekuensi Akses Pornografi Dan Dampaknya Terhadap Perilaku Seksual Pada Remaja Di Kota Bogor (Studi Di SMA Kota Bogor). Jurnal Kesehatan Masyarakat (e-Journal), 8(3), 410-419.

Kuncara, A. W., Sujadi, I., \& Riyadi. (2016). Analisis Proses Pembelajaran Matematika Berdasarkan Kurikulum 2013 pada Materi Pokok Peluang Kelas X SMA Negeri 1 Surakarta. Jurnal Elektronik Pembelajaran Matematika, 4(3), 352-365.

Luthfia, A. (2018). Risiko Online Pada Remaja dan Pendidikan Literasi Media Baru. Jurnal Communicate, 2(1), 13. https://doi.org/10.31479/jc.v2i1.70

Mendrofa, Y. H., Tinggi, S., \& Kesehatan, I. (2019). St Is Be Th Th.

Novita, E., Psikologi, J., Psikologi, F., \& Are, U. M. (2018). ANTHROPOS : Jurnal Antropologi Sosial dan Budaya Faktor-Faktor yang Mempengaruhi Kebiasaan Menonton Film Porno pada Remaja Eryanti Novita. 4(1), 31-44.

Radjagukguk, D. L., \& Yayu Sriwartini. (2020). Peran Orangtua Menyikapi Pornografi Pada Remaja Melalui Komunikasi Efektif. Dinamisia: Jurnal Pengabdian Kepada Masyarakat, 4(2), 354363. https://doi.org/10.31849/dinamisia.v4i2.3765

Sugiono. (2013). metode penelitian kuantitatif,kualitatif dan R\&D. bandung: ALFABETA, CV.

Thalha Alhamid, B. A. (2019). Resume: Instrumen Pengumpulan Data. In Sekolah Tinggi Agama Islam Negeri (STAIN) Sorong.

Utomo. (2018). Perkembangan Mental Remajadi Sekolah. Elementary Vol.6/No.1/Januari-Juni2018, $6(1), 167-187$. 